Erratum

\title{
Propagule pressure: a null model for biological invasions
}

Robert I. Colautti*, Igor A. Grigorovich \& Hugh J. MacIsaac

Great Lakes Institute for Environmental Research, University of Windsor, Windsor, ON N9B 3P4, Canada;

*Author for correspondence (e-mail: rob_colautti@yahoo.com)

Biological Invasions

DOI 10.1007/s10530-005-3735-y

The reference:

Colautti RI (2005) Are characteristics of introduced salmonid fishes biased by propagule pressure? Canadian Journal of Fisheries and Aquatic Sciences 62: In Press

Colautti RI, Muirhead JR, Biswas RN and MacIsaac HJ (2005) 'Realized' vs. 'apparent' reduction in enemies of the European starling (Sturnus vulgaris). Biological Invasions, In Press

are outdated and should now read:

Colautti RI (2005) Are characteristics of introduced salmonid fishes biased by propagule pressure? Canadian Journal of Fisheries and Aquatic Sciences 62: 950-959

Colautti RI, Muirhead JR, Biswas RN and MacIsaac HJ (2005) 'Realized' vs. 'apparent' reduction in enemies of the European starling (Sturnus vulgaris). Biological Invasions 7: 723-732 